\title{
GLOBAL DIFFERENCES IN LABOUR PRODUCTIVITY IN THE AGRIBUSINESS
}

\author{
Aldona Mrówczyńska-Kamińska, $\mathrm{PhD}^{1}$; Bartłomiej Bajan, $\mathrm{MSc}^{2}$
}

Faculty of Economics and Social Sciences, Poznań University of Life Sciences

\begin{abstract}
The purpose of this paper is to assess the global differences in labour productivity in the agribusiness. The relationship between a country's economic development level (measured as GDP per capita) and labour productivity in the agriculture and across the entire agribusiness was measured in 39 countries around the world (which are entered to the World Input-Output Database and for which the relevant I/O tables were prepared) in 2000 and 2014. The input-output analysis, employed as the main research method, enabled the calculation of value added in the agriculture and elsewhere in the agribusiness. The results suggest the existence of a positive linear association between agribusiness labour productivity and economic development level, as corroborated by previous observations. In turn, two separate groups are noticeable in the relationship between agricultural labour productivity and the level of development of a country. In the first group of countries, agricultural labour productivity grows fast as the economy grows whereas in the second group, the growth rate of labour productivity clearly decreases as the economy grows. This study is a part of the discussion on the global agricultural development model which, on the one hand, calls for increasing the productivity of agricultural labour and, on the other, shows a need to reduce environmental degradation.
\end{abstract}

Keywords: agribusiness, labour productivity, economic growth JEL codes: O13, Q00, Q01

\section{INTRODUCTION}

Because repeatable processes are an inherent part of the economy, the researchers have tried to explore the economic transformation patterns since the very beginning of the economic theory. One of the main, empirically proven economic principles is the variability of contributions and roles of different sectors (agriculture, industry, services) in function of economic development levels (Kuznets, 1973). As the development processes advance, the national economy becomes dominated by modern industry and services, whereas the share of sectors directly related to food manufacturing tends to decline (Kuznets, 1976). The agriculture sector becomes primarily a supplier of products to be processed. Also, the supply and service areas (which provide the agriculture sector with productive inputs) start to exert an increasingly powerful impact on food manufacturing. As a consequence of increasingly stronger links between economy sectors related to food manufacturing, the agribusiness emerges as a distinct system (Davis and Goldberg, 1957).

The essential condition for economic growth is the increase in labour productivity. For the agricul-

${ }^{1}$ Corresponding author: Wojska Polskiego 28, 60-637 Poznań, Poland, mrowczynska-kaminska@up.poznan.pl, +4861 8466374

${ }^{2}$ Corresponding author: Wojska Polskiego 28, 60-637 Poznań, Poland, bartlomiej.bajan@up.poznan.pl, +4861 8466379 
ture, this usually means greater environmental degradation resulting from large quantities of fertilizers or pesticides, for instance (Pearce, 2002). Therefore, some communities call into question the continuous pursuit of general productivity, including labour productivity. These are the conclusions that may be drawn, for instance, from the sustainable development concept which places environmental aspects on an equal footing with socio-economic factors (Goodland, 1995). The agricultural policies implemented by developed countries increasingly often, and to an increasingly greater extent, put much emphasis on the environmental aspect, as illustrated by the example of successive reforms of the European Union's Common Agricultural Policy or the American Farm Bill as well as in the United Nations environmental programs (Dokurno, Fiedor and Scheuer, 2016).

Therefore, the purpose of this paper is to assess the differences in labour productivity in agribusiness around the world which are related to country's development level. Also, the research attempts to answer the question whether the current agribusiness development state provides grounds to believe that the economy may continue to grow despite a concurrent decline in the growth rate of agricultural labour productivity. This study is a part of the discussion on the global development model for the agriculture and agribusiness which, on the one hand, calls for increasing the productivity of agricultural labour and, on the other, shows a need to reduce environmental degradation.

\section{THEORETICAL BACKGROUND}

The objective of each economic development strategy is to move from an agriculture-based economy to one not dominated by the agricultural sector. Consequently, in poorly developed countries, the contribution of agriculture to the GDP usually ranges from 40 to $60 \%$, and the share of population employed in the agricultural sector is 50 to $80 \%$. However, such an intensive use of resources results in low productivity levels (Johnston and Mellor, 1961). As the incomes grow, the population spends more and more on goods related to non-agricultural sectors of the economy. As a consequence, a part of the labour force moves to these very sectors; although less people work in ag- riculture, they still must produce food to address the needs of the society (Mellor, 1982). The conclusion from the above argument is that the increase in agricultural productivity is not only necessary but also inevitable. This is particularly important in the context of the forecasted growth of global population and related challenges faced by the 21 st century society. Obviously, the above does not mean labour productivity is the only driver of growth. The transformation of the food economy is affected by various aspects, regarded as the driving forces and the restrictions and barriers which may be grouped into exogenous and endogenous factors. Exogenous factors include the country's development level, the contribution of agriculture to GDP and the level of food expenditure whereas endogenous factors include the employment share of agriculture, farm structure, production scale and labour productivity (Tomczak, 2004).

The abovementioned principles of agricultural development are reflected in the concept proposed by Davis and Goldberg (1957) who define agribusiness as a combination of all agricultural production operations together with the production and distribution of the entire flow of supply in productive inputs and production services intended for the farms, as well as all operations related to trading, storage, processing and distribution of agricultural products. Agribusiness is composed of 3 spheres: sphere 1 means the industry sectors which deliver productive inputs and services to the agriculture and food sectors (provisioning); sphere 2 means agriculture; sphere 3 means the food sector (Davis and Goldberg, 1957). As the economy grows, the importance of specific components of the food production chain changes. The trend resulting from the world agriculture development patterns suggests that non-agricultural links gain in importance to the detriment of the agriculture itself. Specifically, this means an increased share of sphere 3 and sphere 1 with a decline in sphere 2 (Wilkin, 2001).

The above relationships are corroborated by the global agriculture development path, a concept by Tomczak (2004) which presents several patterns, including a positive linear association between agricultural labour productivity and national development level around the world in 1995-1997 (Tomczak, 2004). The research presented in this paper focuses 
on that very relationship, in the context of both the agriculture and the entire agribusiness.

\section{MATERIALS AND METHODS}

The analysis covered all countries entered to the World Input-Output Database (WIOD) for which the corresponding I/O tables were prepared, except for Cyprus, Malta, Luxembourg and Taiwan ${ }^{3}$. The input-output analysis, employed as the main research method, enabled the calculation of output in the agriculture and elsewhere in the agribusiness as per the formula proposed by Woś (1979):

$$
X_{A}=x_{r}+x_{p}+\sum_{i=1}^{n} x_{i} b_{i r}+\sum_{i=1}^{n} x_{i} b_{i p}
$$

with:

$X_{A}-$ output of agribusiness,

$x_{r}-$ output of agriculture,

$x_{p}-$ output of the food industry,

$x_{i}-$ output of industry (sector) $i$ which is related to the agriculture and food industry $(i+1,2, \ldots$, $n, n \neq r, p)$ and is indirectly involved in food production,

$b_{i r}-$ coefficient specifying the flow of products and services from industry (sector) $i$ to the agriculture, expressed as a percentage of intermediate demand of industry (sector) $i$,

$b_{i p}-$ coefficient specifying the flow of products and services from industry (sector) i to the food industry, expressed as a percentage of intermediate demand of industry (sector) $i$.

Just as in the case of output, the same method was used to calculate the value added in agribusiness. The product and service $\mathrm{I} / \mathrm{O}$ coefficients were used to determine the size of labour force engaged in agribusiness production. Data from the WIOD Socio-Economic Accounts was used for that purpose. In turn, labour productivity was calculated based on value added per person engaged, and the level of economic development was measured as per capita GDP in purchasing power parities (in USD). GDP figures were retrieved from the World Bank database. The calculations were based on data from 2000 and 2014, the initial and final year for which $\mathrm{I} / \mathrm{O}$ tables were calculated in the WIOD database (2016 Release). With this approach, it is possible to trace the evolution, if any, of the development path of the global agriculture (and of the entire agribusiness) in a longer term perspective.

\section{RESULTS AND DISCUSSION}

The theoretical assumptions would suggest that - because of higher labour productivity in non-agricultural spheres - the agribusiness as a whole demonstrates a higher labour productivity than the agriculture itself. While most calculations shown in Table 1 confirm the above, there is a small group of countries where labour productivity in agriculture comes very close to (or sometimes even exceeds) that of agribusiness as a whole. This becomes particularly evident when looking at 2014 figures recorded in Australia, Canada, United States and Slovakia. The first three countries are often cited as an example of a highly industrialized agriculture characterized by high levels of production intensity (Cockfield, Mushtaq and White, 2012; Parcerisas and Dupras, 2018); this suggests a positive correlation between production intensity and labour productivity. In all countries surveyed, labour productivity levels grew from 2000 to 2014 in all spheres of agribusiness. At the same time, labour productivity is on average higher in the food industry. However, there are many countries where the highest levels of labour productivity are reported in the provisioning sphere. This may be caused by many factors, primarily including the national agribusiness development model, its structure and links to other sectors of the economy.

The research suggests that a linear relationships exists between labour productivity in agribusiness as a whole and economic development levels. The above conclusion can be drawn based on both 2014 data (as shown in Fig. 1) and 2000 data $^{4}$.

\footnotetext{
${ }^{3}$ Because of their small area or geographic location, these countries are not representative for this study.

${ }^{4}$ In 2000 and 2014, for these values, the coefficient of determination (R2) was 0.88 and 0.86 , respectively. Both of these levels suggest the model is well fitted. The Pearson correlation coefficient is positive and high (0.94 in 2000 and 0.93 in 2014) for both features. This means the agribusiness labor productivity grows as the economy grows.
} 
Proceedings of the 2018 International Scientific Conference 'Economic Sciences for Agribusiness and Rural Economy' No 2, Warsaw, 7-8 June 2018, pp. 191-197

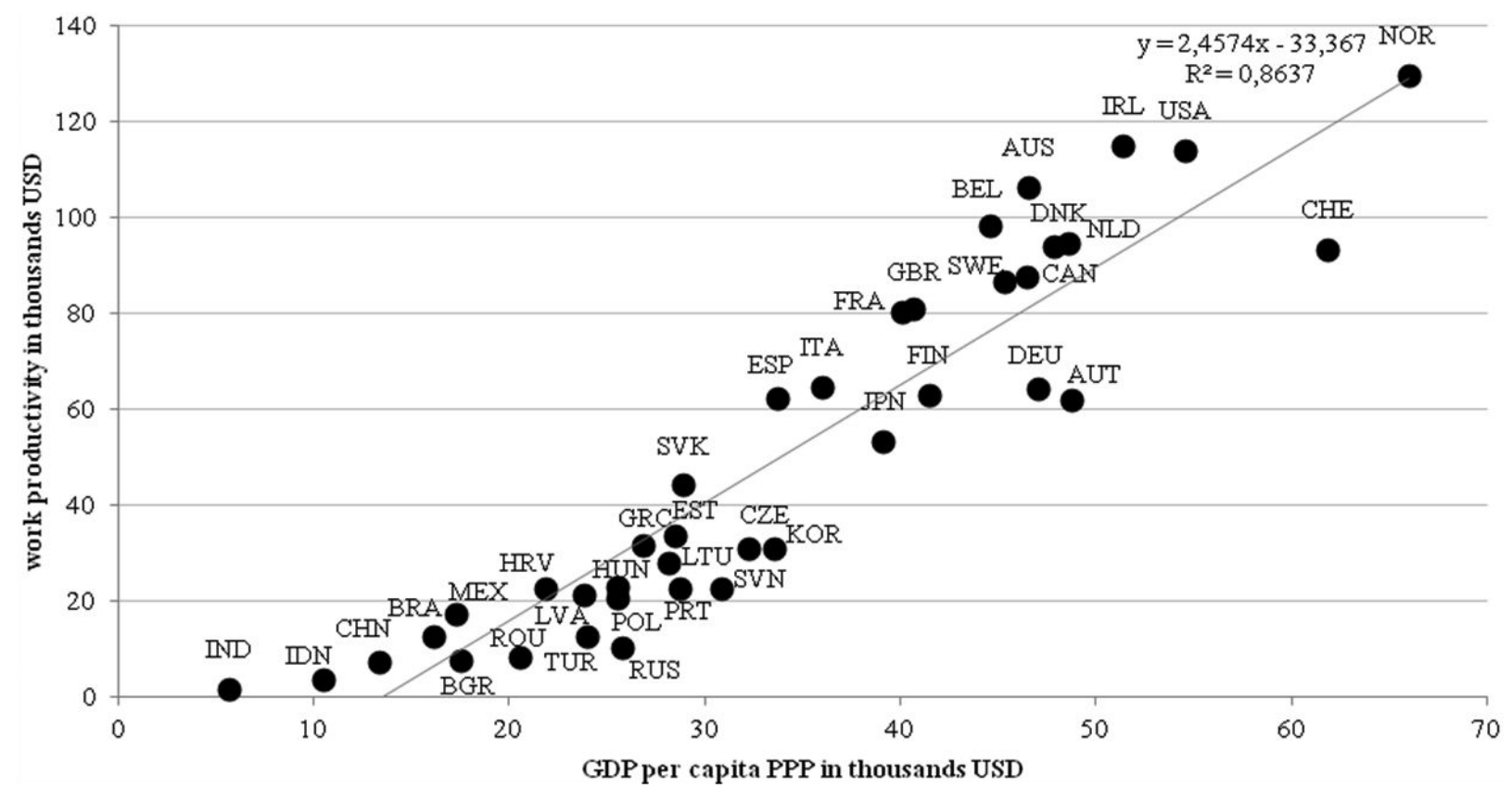

Figure 1. Relationship between agribusiness labour productivity and GDP per capita in 2014

Source: own elaboration based on World Bank data and WIOD.

Norway, the most developed of the countries considered, had a GDP per capita of over USD 66,000 in 2014 while also demonstrating the highest productivity of labour in the agribusiness as a whole (USD 130,000 per person engaged). At the other end of the spectrum, India has the lowest GDP per capita of all the countries surveyed (not in excess of USD 6,000 in 2014), and demonstrates the lowest productivity of agribusiness labour (ca USD 1,000 per person engaged). The relationship between economic growth and productivity may be reciprocal because a potential increase in value added results in improved labour productivity; at the same time, a higher value added directly contributes to increasing the GDP (as a component thereof). This path of agribusiness development requires labour productivity to be increased. However, according to data in Table 1, it does not necessarily have to grow at an even rate across all agribusiness spheres. Note also that different sectors of the economy which compose the agricultural sector rely on labour inputs to a various extent.

This is particularly noticeable in highly developed countries which report considerable differences in labour productivity between different spheres of the agribusiness. For instance, labour productivity in the Irish food industry in 2014 was USD 214,000 per person engaged. Meanwhile, in the United States - the country with the most similar development level of all the countries surveyed - it was USD 142,000. In Ireland, in the same year, labour productivity in agriculture was at a relatively low level of USD 33,000 per person engaged while in the United Stated it was as much as USD 112,000. Both countries recorded the most similar levels of labour productivity in the provisioning area, with USD 121,000 and USD 105,000 in Ireland and in the United States, respectively.

This is particularly important for the agriculture itself as an increase in labour productivity often has an adverse environmental impact. As shown by this study, already in 2000, some countries who experienced economic growth reported a smaller growth rate of agricultural labour productivity compared to other countries. In 2000, the coefficient of determination of a linear model with these two features was 0.67 . This suggests the model is satisfactorily explained by the linear trend, though to a lesser degree than for the agribusiness as a whole. Figure 2, based 
Table 1. Labour productivity in different agribusiness spheres in 2000 and 2014 (value added per person engaged)

\begin{tabular}{|c|c|c|c|c|c|c|c|c|}
\hline \multirow{3}{*}{ Specification } & \multicolumn{2}{|c|}{ Provisioning } & \multicolumn{2}{|c|}{ Agriculture } & \multicolumn{2}{|c|}{ Food industry } & \multicolumn{2}{|c|}{$\begin{array}{l}\text { Agribusiness } \\
\text { as a whole }\end{array}$} \\
\hline & \multicolumn{8}{|c|}{ USD thousand } \\
\hline & 2000 & 2014 & 2000 & 2014 & 2000 & 2014 & 2000 & 2014 \\
\hline Australia & 37 & 107 & 32 & 110 & 46 & 100 & 37 & 106 \\
\hline Austria & 48 & 90 & 12 & 23 & 42 & 89 & 28 & 62 \\
\hline Belgium & 50 & 107 & 34 & 57 & 51 & 106 & 47 & 98 \\
\hline Brazil & 7 & 19 & 2 & 7 & 8 & 20 & 3 & 13 \\
\hline Bulgaria & 4 & 14 & 2 & 4 & 3 & 15 & 2 & 8 \\
\hline Canada & 43 & 85 & 28 & 83 & 56 & 94 & 41 & 86 \\
\hline China & 2 & 10 & 1 & 5 & 4 & 25 & 1 & 7 \\
\hline Croatia & 12 & 30 & 4 & 11 & 2 & 34 & 6 & 22 \\
\hline Czech Republic & 12 & 35 & 8 & 25 & 13 & 33 & 11 & 31 \\
\hline Denmark & 51 & 105 & 38 & 65 & 50 & 100 & 47 & 94 \\
\hline Estonia & 9 & 38 & 5 & 29 & 7 & 30 & 7 & 33 \\
\hline Finland & 47 & 95 & 14 & 24 & 41 & 90 & 30 & 63 \\
\hline France & 47 & 89 & 30 & 54 & 52 & 93 & 43 & 80 \\
\hline Germany & 41 & 75 & 24 & 34 & 36 & 61 & 36 & 64 \\
\hline Greece & 28 & 45 & 10 & 15 & 28 & 59 & 17 & 32 \\
\hline Hungary & 10 & 27 & 4 & 19 & 8 & 23 & 7 & 23 \\
\hline India & 1 & 4 & 0.4 & 1 & 1 & 2 & 1 & 2 \\
\hline Indonesia & 1 & 4 & 1 & 2 & 4 & 21 & 1 & 4 \\
\hline Ireland & 52 & 121 & 20 & 33 & 60 & 214 & 40 & 115 \\
\hline Italy & 44 & 76 & 27 & 47 & 46 & 73 & 38 & 64 \\
\hline Japan & 65 & 66 & 16 & 19 & 99 & 100 & 49 & 53 \\
\hline Latvia & 8 & 31 & 2 & 9 & 10 & 26 & 5 & 21 \\
\hline Lithuania & 8 & 35 & 2 & 12 & 9 & 46 & 5 & 28 \\
\hline Mexico & 22 & 34 & 4 & 6 & 27 & 43 & 10 & 17 \\
\hline Netherlands & 44 & 87 & 39 & 74 & 65 & 145 & 46 & 94 \\
\hline Norway & 68 & 165 & 17 & 55 & 47 & 125 & 47 & 130 \\
\hline Poland & 13 & 36 & 2 & 8 & 11 & 31 & 5 & 20 \\
\hline Portugal & 23 & 47 & 5 & 7 & 18 & 45 & 10 & 23 \\
\hline Romania & 5 & 17 & 1 & 3 & 11 & 52 & 2 & 8 \\
\hline Russia & 5 & 24 & 1 & 4 & 4 & 25 & 2 & 10 \\
\hline Slovakia & 9 & 39 & 7 & 63 & 8 & 32 & 8 & 44 \\
\hline Slovenia & 21 & 49 & 5 & 9 & 21 & 41 & 11 & 22 \\
\hline South Korea & 24 & 43 & 10 & 19 & 26 & 50 & 14 & 31 \\
\hline Spain & 30 & 64 & 22 & 44 & 31 & 85 & 27 & 62 \\
\hline Sweden & 53 & 109 & 19 & 28 & 55 & 113 & 42 & 88 \\
\hline Switzerland & 66 & 139 & 15 & 30 & 58 & 130 & 38 & 93 \\
\hline Turkey & 15 & 25 & 3 & 8 & 15 & 32 & 6 & 13 \\
\hline United Kingdom & 46 & 84 & 35 & 43 & 62 & 113 & 49 & 81 \\
\hline United States & 66 & 105 & 43 & 112 & 91 & 142 & 67 & 114 \\
\hline
\end{tabular}

Source: own elaboration based on WIOD data. 


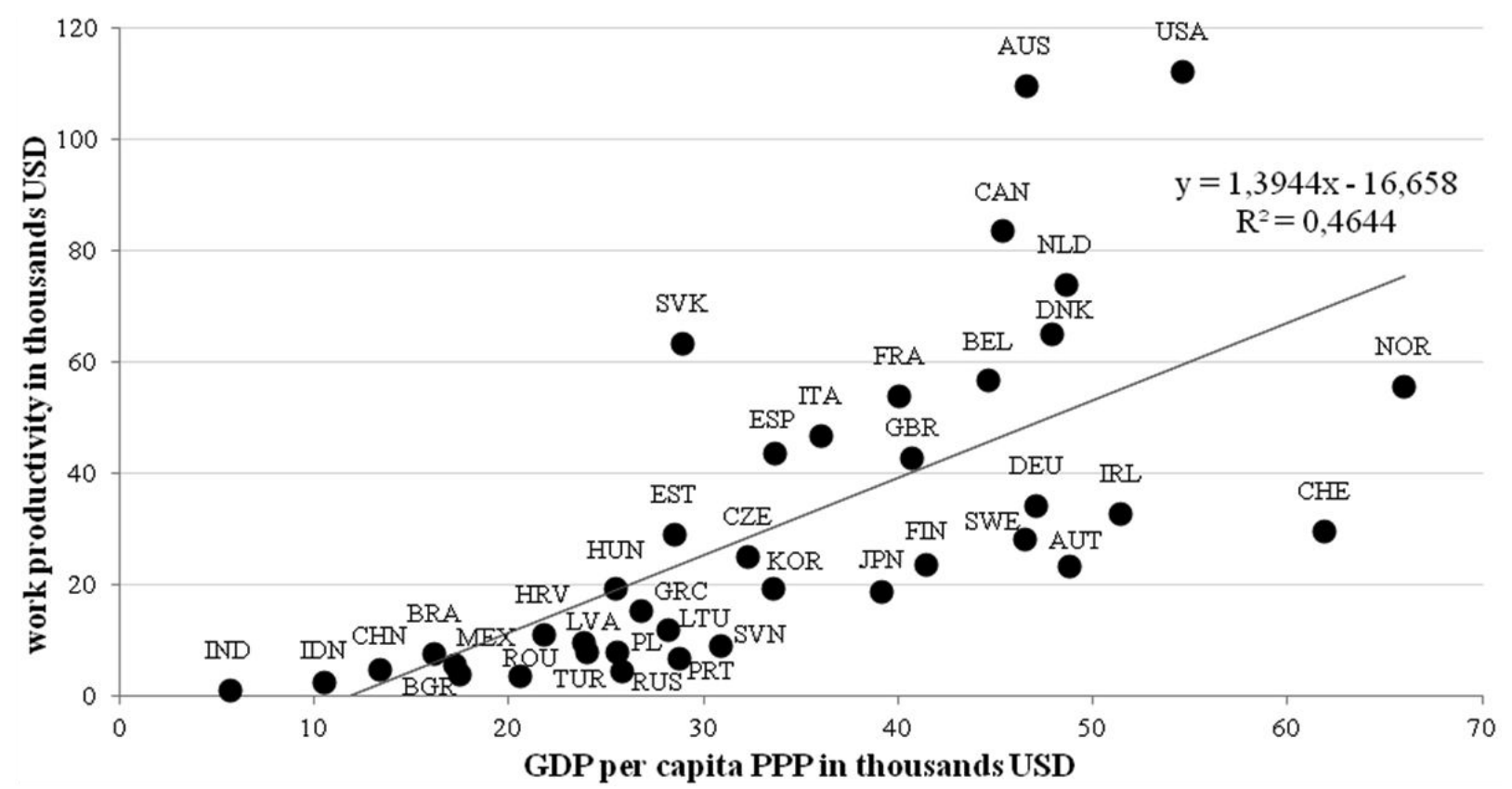

Figure 2. Relationship between agricultural labour productivity and GDP per capita in 2014

Source: own elaboration based on World Bank data and WIOD data.

on 2014 data, clearly shows two separate groups of countries with different work productivity in agricultural.

A group of countries which include the United States, Australia, Canada, the Netherlands and Denmark demonstrate a high level of agricultural labour productivity (much above USD 60,000). In turn, in another group which includes Ireland, Germany, Austria and Sweden, labour productivity is considerably lower, reaching a level of up to USD $40,000^{5}$. Note also that both groups are at a similar level of economic development, with a per capita GDP ranging from USD 45,000 to USD 55,000. These figures suggest the countries may choose between a faster or slower growth of agricultural labour productivity. However, the following question needs to be considered: if low levels of agricultural labour productivity were characteristic for all highly developed countries, would the output of agricultural raw materials be enough to address the demand in the context of such issues as population growth? This is an important problem because the answer to that question should offer a clear direction for the development of agriculture and of the entire agribusiness for the countries which embark on this path (i.e. those with a low per capita GDP and a low level of labour productivity). However, note that according to the agribusiness development presented in this paper, the economy cannot grow if the increase in labour productivity in different spheres of agribusiness (including the agriculture) is completely stopped.

\section{CONCLUSIONS}

The analysis demonstrated the existence of two development paths for the agriculture and agribusiness in the context of labour productivity gains. On the one hand, there is a group of countries where agricultural

\footnotetext{
${ }^{5}$ The second group could also include Norway and Switzerland with labor productivity levels of USD 55,000 and USD 30,000 , respectively. However, both of these countries report a much higher GDP per capita.
} 
labour productivity grows fast as the economy grows, while on the other, there are countries where labour productivity grows at a much slower rate. Interestingly, as the economy grows, labour productivity increases linearly in the entire agribusiness. This suggests that an important role is played by non-agricultural areas where labour productivity contributes to the linear nature of the agribusiness development path. The development level of non-agricultural areas of agribusiness depends on multiple factors and differs considerably from one country to another. Therefore, it is difficult to identify a unique general pattern for labour productivity.

This study is a part of the discussion on the development model for the global agriculture and the entire agribusiness which, on the one hand, calls for increasing the productivity of agricultural labour and, on the other, shows a need to reduce environmental degradation which is often the consequence of gains in labour productivity. Whether the countries at lower levels of socio-economic development will follow the road paved by countries around the world characterized by a fast increase in labour productivity, or will they choose a totally different development path in the food manufacturing area, remains an open question. And there is no obvious answer to that. It can only be concluded that work productivity will be a milestone for both development paths, and the growth rate will be by far lower if the sustainable growth paradigm is adopted.

\section{REFERENCES}

1. Cockfield, G., Mushtaq, S., White, N. (2012). Relocation of Intensive Agriculture to Northern Australia: The Case of the Rice Industry. Technical Report, University of Southern Queensland, Toowoomba, Australia.

2. Davis, J.H., Goldberg, R.A. (1957). A Concept of agribusiness. Division of Research, Graduate School of Business Administration. Harvard University, Boston.
3. Dokurno, Z., Fiedor, B., Scheuer, B. (2016). Makroekonomiczna i metodologiczna perspektywa dyskursu wokół pojęcia zielonej gospodarki [The discourse on the green economy from macroeconomic and methodological perspective]. Gospodarka Narodowa, 1 (281), pp. 5-28.

4. Goodland, R. (1995). The Concept of Environmental Sustainability. Annual Review of Ecology and Systematics, 26, pp. 1-24.

5. Johnston, F.B., Mellor, J.W. (1961). The role of agriculture in economic development. American Economic Review, 51 (196), pp. 566-593.

6. Kuznets, S. (1973). Modern Economic Growth: Findings and Reflections. American Economic Review, 63 (3), pp. 247-258.

7. Kuznets, S. (1976). Wzrost gospodarczy narodów. Produkt i struktura produkcji [Economic growth of nations: total output and production structure]. PWE, Warszawa.

8. Mellor, J. (1982). Agricultural Growth - Structures and Patterns. In: Proceedings of IAAE Annual Conference. Jakarta, 24.08-02.09.1982, pp. 216-228.

9. Parcerisas, L., Dupras, J. (2018). From mixed-farming to intensive agriculture. Energy profiles of Quebec's agriculture between 1871 and 2011. Regional Environmental Changes. DOI: https://doi.org/10.1007/s10113018-1305-y

10. Pearce, D. (2002). An Intellectual History of Environmental Economics. Annual Review of Energy and the Environment, 27, pp. 57-81. https://doi.org/10.1146/annurev.energy.27.122001.083429

11. Tomczak, F. (2004). Od rolnictwa do agrobiznesu. Transformacja gospodarki rolniczo-żywnościowej Stanów Zjednoczonych Ameryki Północnej [From agriculture to agribusiness. Transformation of the US agri-food economy]. Warsaw School of Economics, Warszawa.

12. Wilkin, J. (2001). Polskie rolnictwo wobec procesu globalizacji [Polish agriculture in the context of the globalization process]. Roczniki Naukowe SERiA, 3 (1), pp. 9-20.

13. Woś, A. (1979). Związki rolnictwa z gospodarką narodową [Relationships between agriculture and national economy]. PWRiL, Warszawa. 